\title{
Gender Bias in The Rural Community as Reflected in Minfong Ho's Sing to The Dawn
}

\author{
Hermanus Wahyaka
}

\section{Abstract}

This study aims at identifying the evidences of gender-biased behaviour and actions and at finding the possible reasons why those gender-biased behaviour and actions happen within the life of the rural community as depicted in the novel. The problems, therefore, are formulated as follows: 1). What are the evidences of gender-biased behaviour and actions experienced by the major female characters of Ho'sSing to the Dawn?and 2). Why do the gender-biased behaviour and actions occur within the life of the rural communityas in Ho'sSing to the Dawn?

This study is a library research. The primary source is the novel itself, Sing to the Dawn. The secondary sources are obtained from several relevant books related to literary theories such as the critical approach, the theory of gender, the theory of society, and the review of Thai society. In order to relate the gender bias and a certain community, the socio-cultural approach is used to examine the novel.

This study found that gender biased behaviour and actions committed by the male characters towards the major female characters manifest in several manners; they are subordination of women, mental violence, violent intention, physical violence, sex role stereotyping, and marginalization. The possible reasons enabling the manifestation of gender biased behaviour and actions committed by the male characters towards the major female characters are cultural construction on women subordination, cultural construction on sex roles stereotyping as the result of patriarchal system, religious misinterpretation, and poverty.

Keywords: gender bias, female characters,rural community.

\section{A. INTRODUCTION}

Novel, as one of the literary works, has become the common way to show human's feelings in dealing with their environment for centuries and it does not show any signs of weakening. On the other hand, the readers consider that novels are the most flexible type of literary works and contain a lot of possibilities (Madden, 2009). As a medium to express mind, novels have had great influences in people's life. A novel, for instance, has a power to see deeply the situation the universe faces and it represents the human condition both on the individual level and on social level (Madden, 2009). One of the issues occurred in a society viewed deeply through novels is the biased perception or unbalanced roles between men and women.

An individual of a particular society develops his or her knowledge and cognition in the whole society's system by interacting and getting involved in the social events happening in the environment. The primary socializations are the process of the society's culture internalization and the process of structuring the personality. "The child's personality is moulded in terms of the central values of the culture to the point where they become part of the child." (Haralambos, 1996: p. 383). 
This kind of interaction then forms and influences individual perspectives towards his or her environment or even greater, towards the society itself. This influence, according to Tharp and Gallimore (1998), could be projected in the area of teaching, schooling, and education. In addition, these kinds of interaction later will shape the perspectives of his or her environment, for instance the perspective towards social orders, social roles, social functions, et cetera.

This condition generates cultural reproduction. Pierre Bourdieu (1973) as cited by Edgar and Sedgwick (2002) defined cultural reproduction as a process by which the culture is maintained from one generation to the next through the education system. In this process, individuals internalize the culture through their societies or in other words, cultural transmission occurs. The cultural transmission will not only simply "maintain the stability of the manner in which the society is organized, the stability of the key values and beliefs of its culture but rather the stability of the political structures and the structures of domination and exploitation within the society" Edgar \& Sedgwick (2002: 100).

Caregivers, as parts of a society, are agents of social perspectives. Trevarthen, as stated by Adamson and Chance (1989), states that caregivers or parents will introduce the society's set of cultural knowledge to their children. These children then learn and absorb anything in the society through what they have seen in their parents or adults. This social interaction affects their cognitive development. Caregivers' inappropriate cultural knowledge, therefore, will mislead their children's views towards their society.

The misunderstanding of social perspectives as an effect of improper caregivers' cultural knowledge may happen in unbalanced views towards differences of role between men and women. The assumption that men are super-ordinate and that women are subclasses of men is one of that lacking of cultural knowledge (Glover \& Cora, 2005).

In Ho'sSing to the Dawn, the main character, a girl, is always positioned in the second place. In addition, the other female characters depicted in this novel also have more or less similar experiences to the main character. This condition reflects that the society where the main character lives allows men to place women in the sub-ordinate position. Sukanto (1990: 405) states that these conditions are the products of social interaction. The author's has succeeded in delivering messages that everyone must take risks in this life, or else, the life will be worthless. If the main character of this novel had not takena risk, the story would have been different and remained as a potboiler.

The main character represents the courage to face injustice of a community or a society. As the main character, Dawan, underlines the importance of being educated to bring about positive changes of a society, "Studying should be a way of learning how to help our people, and not just swallowing down and spewing up the words in textbooks," (Ho, 2005: 43). As the ideal consequence, educated people will not leave their origin only to pursue their personal interests. Conversely, they will try to do the best efforts they can for their society (Ho, 2005: 51; 118).

Thus, this paper aims to answer the following research questions:

1. What are the evidences of genderbiased behaviour and actions experienced by the female characters of Ho'sSing to the Dawn?

2. Why do the gender-biased behaviour and actions occur within the life of rural community as in Ho'sSing to the Dawn? 


\section{B. REVIEW OF RELATED LITERATURE 1. Socio-cultural Approach}

Literature describes human beings and the situations in a particular context. To study literature only in the light of culture, however, will deduce literature into a branch of sociology (Das, 2002. Rohrberger and Woods (1971) stated that socio-cultural approach is one of approaches in critical approach. It focuses on the civilization and the effects of the civilization to the community or society and the culture. Rohrberger and Woods (1971) stated that the major interest of socio-cultural approach as "the only way to locate the real work is in reference to the civilization that produced it."

Civilization is attitudes and actions of a particular group of people and point out that literature takes these attitudes and actions as its subject matter. It is, therefore, necessary that the critic investigates the social milieu in which a work was created and which it necessarily reflects (Rohrberger and Woods, 1971).

\section{The Theory of Gender}

Nowadays, gender is one of the widely used terms in English language (Glover \& Cora, 2005; Megawangi, 1999) and even greater in the third world during these 20 years (Fakih, 2010) as gender is interrelated to injustices in this life. Gender and sex are two different terms. Edgar \& Sedgwick (2002) and Fakih (2010) underline the two terms. They stated that sex refers to two biological sexes; they are male or female, while gender is a matter of culture. Gender refers to behaviour and actions and the characterization of men and women constructed socially and culturally and that these cultural and social constructions are different from time to time and they adjust from one culture to another. Stoller in Glover
\& Cora (2005) stated that gender is to signal complexities of those countless areas of behaviour, feelings, thought, and fantasies related to the sexes yet do not have primarily biological connotations.

Despite Edgar \& Sedgwick, Fakih, and Glover \& Cora, another intellectual, Eisenstein (1983: 7) defines gender as a cluster of expectations, attributes, and behaviour shaped culturally and socially assigned to that category of human being by the society into which the child was born. These gender differences and sexual identity are initiated at the age of 18 months and are formed, socialized, affirmed, and constructed culturally and socially through religious interpretations and state interventions (Fakih, 2010).

Anthropological studies on the family woman's subordination conducted by Rubin as cited by Glover and Cora (2005) inferred that men typically have certain rights in their female family and relations. Women, conversely, do not have the same rights in their male family and relations and they may be used as bride wealth, trophies, gifts, and even traded, bought, and sold.

The perspective leads social thoughts to the sex roles and sexrole stereotyping. Jeneway and Millet highlight the definition of sex role as "a role assigned to the actor because of the gender-associated behaviour linked by society with that biological sex" (Eisenstein 1983, 11; Haralambos, 1996). Women are associated with lower order of social or cultural organization, domestic and private sphere and they should be accustomed to doing domestic jobs like taking care of the children, cooking, and other trivial household jobs. Men, on the other hand, tend to be associated with public sphere, higher order, and they should be looking for family subsistence, 
chief of the family, decision maker, and so on. These kinds of sex-role stereotyping become the means by which the entire society keeps women as subject to the rules of the patriarchy (Eisenstein, 1983: 6).

This is what then called as gender bias. Glenn (1994) as cited in Cheal (2002) underlines that gender bias acts, like mothering, have deep and great effects on the lives of women. It relates to social identity which is defined as a set of personal characteristics that are believed to be similar to someone occupying a particular social role or who belongs to a particular social category.

Jere Behrman as cited by Megawangi (1999) in the household resource allocation theory shows that women tend to be put in the second priority if the family where the women live is living in abject poverty. The resource of the family will be projected to the most profitable sector. The men, in this context is the sons, will have the priority in getting the education. The cultural features are subjects to legitimate this pure investment model. The culture will interact with biological factors and this later becomes institutionalized.

Fakih (2010) identifies several manifestations of the gender inequalities between men and women in social life, especially towards women, they are: marginalization of women, subordination, stereotyping, violence, and double burden. Marginalization of women is a conditioning at the level of state policies, beliefs system, religious interpretation, and domestic areas. Subordination of women happens in the assumption that women does not need to take any higher education than men. Stereotyping of women is taking women only into the domestic job and to serve men or husband and to take care of the children.
Michelle Rosaldo (1974) in Haralambos (1996) classified two domains related to the differentiation of roles between men and women; they were domestic and public spheres. Domestic sphere covers "the institutions and modes of activity that are organized immediately around one or more mothers and their children. Women are associated with this sphere." (Haralambos, 1996: 468). This assigns women to deal with family life and domestic jobs. Yet men are associated with public sphere, id est activities, institutions, and forms of association that link, rank, organize, or sub-sum particular motherchild groups such as in the activities of rituals and religion, politics, and the economy (Haralambos, 1996).

Violence, in sociological discussion, is any acts which are intended to cause physical and mental pain or serious injury to another person. Abuse, as the part of violence, is any acts which have a probability of long-term mental, psychological, and emotional harms to the person or whom it is inflicted (Cheal, 2002). Gender-related violence includes among others sexual abuse, physical and mental assault at domestic sphere, genital mutilation to control women, pornography in which women's body is exploited for profit, enforced sterilization, et cetera.

\section{The Theory of Society}

Merriam-Webster's Collegiate Dictionary (2001; 1111) defines society as "a community, nation, or broad grouping of people having common traditions, institutions, and collective activities and interests." In Edgar \& Sedgwick (2002: 368), society is defined as "a collection of free agents whose properties and characteristics are constituted independently of the modes 
of relationship which operate within any particular context." Likewise, society in sociology and interactionist approaches, is defined as terms of abilities of individuals to make sense of their social environment and react to it in an independent way (Edgar \& Sedgwick, 2002).

Yet, the world in the novel and the actual world in which the author lives are two different things. Society in the novel is one of the elements of novels that functions as an aspect in a structure that is self-referential as a concept and a construct in fiction (Langland, 1984). Langland $(1984 ; 5)$ stated that "society in the novels does not depend solely on the points of absolute fidelity to an outside world in details of costume, setting, and locality because a novel's society does not aim at a faithful mirror of any concrete, existent thing."

Related to gender inequality and society, Gayle Rubin (1975) as quoted by Haralambos (1996) explained that society had been culturally elaborating the distinction between the sexes for generations. Every society had a sex or gender system which determined culturally the definition of sex and gender. Gender, according to Erving Goffman as mentioned in Haralambos (1996), expresses the requirements of social situations and it is not an essential human nature.Ortner(1979) furthers criticizes that gender is the product of society resulted from the way every culture defines and evaluates "female biology." That women are inferior to men is caused by the assumption that women are closer to the nature and natural processes as seen in the menstruation, pregnancy, child-birth, and lactation (Haralambos, 1996).

\section{B. Review of Thai Society}

Sing to the Dawntells about the lives of rural Thai people in general, a review of rural Thailand is needed. It is to clarify the setting of the novel and to help the analysis of the second problem formulated. This review is mainly focused on the development of rural areas of Thailand in 1970's as the novel describes the condition of rural Thailand in that period (Ho, 2005).Thailand in general is a developing country and its development has started in the 1960s by adopting the first 6-year economic plan in 1961 (Yamklinfung, 1987). These development efforts have brought changes to Thai society, both the negative and positive changes.

The economic growth has achieved a significant progress, but the problems of rural-urban disparities do exist. It is because thegovernmentconsidersthatrich economic development will immediately influence the economic development of the poor people. Conversely, the rich get richer while the poor get poorer. Rural population suffering from exploitative middlemen, money lenders, and landlords and the negligence of government as well has led the students to protest against this kind of injustice.

The society of Thailand is stratified into three classes, they are kin of reigning king and his immediate predecessors, government officials, and peasantry as the largest group. The classes who have political power and status have greater access to wealth. The Buddhist monks have special status outside this system. Abbots and monks often get distinct prestige within communities (Hoare, 2004).Rural families commonly live in villages, earn money by cultivating land, and some of those families are rich and hold large quantity of land. The rich 
peasants hire labours and the landless or peasants with too little land work for wages (Yamklinfung, 1987).

\section{DISCUSSION}

This paper tries to find the evidences of gender-biased behaviour and actions towards the female characters. Secondly, it is to find possible reasons why gender-biased behaviour and actions happen within the life of rural community as described in the novel. Socio-cultural approach and related theories are the basis for the data findings of those two proposed problems.

\section{A. The Evidences of Gender Bias Experienced by the Major Female Characters}

In this Ho's novel, Sing to the Dawn, Dawan, the main character, is a girl living in a rural community in Thailand. In that community, the people are living in abject poverty, ups and downs through the hardships. Most of the people are landless farmers. These facts can be inferred from the students' responses when answering the teacher's questions in a class discussion as follows:

"Look, this is really important," the teacher said, frowning impatient himself. "Put everything else you may have on your mind aside, and think about this for the moment. What did you see beneath your homes this morning?"

...

There was a rustling of soft words, "Rice ... sacks," "Piles of it ..." "Our rice ..." The teacher nodded. "Sacks of rice. Outside almost every home. Now, what is this the rice for?"

Finally a boy in the back row raised his hand and stood up reluctantly. "It's rent for the landlord, sir," he muttered, and sat down hurriedly again. (p. 18)
There are several female minor characters in the novel, they areDawan's mother, Dawan's cousin Noi, and Dawan's new-found friend Bao.In this part, the writer analyses the events in the novel showing the evidences of gender-biased behaviour and actions committed by male characters towards the major female characters, which manifest in some ways, such as physical and mental violence, marginalization of women's role in society, subordination, and stereotyping of women.

\section{Subordination of Women}

This paradigm is the most common and clear evidence of gender-biased behaviour and actions towards women. It happens when the main character's father thinks that it is useless to send his daughter to school.

"Although Dawan was already fourteen, and a year older than her brother, she was in the same class as he was. Their parents had considered it foolish and wasteful to send girls to school. It was not until Kwai had started school himself and kept insisting that his sister be allowed to join him that Dawan was finally permitted to go." (p. 14)

In the other occasion, Dawan's father underlines that women are not in the top priority of attending school when he is speaking to Dawan's younger brother, Kwai.

"If you'd won, of course it'd be different," the father answered. "You're a boy, and more schooling would have been useful for you. ... with more schooling, you could find good jobs, and earn some money to help the family." (p. 55)

Another male character, Dawan's cousin husband, Ghan, also puts women as the second class when he gives some pieces of advice to Dawan and Dawan's mother on Dawan's will to leave for the City school. 
"That's true," Ghan confirmed. "There's no sense in a young girl going off into the City alone." (p. 35)

Women are subordinate. "We girls have always had to stand aside and let our brothers do all the challenging things. And when we become wives, we'll have to stand aside for our husbands. And when we're mothers, we'll stand aside for our children." (p. 79). "But what right does your sister have? She's only a girl." (p.103). "Because you are only a girl, because there's nothing you can do, even with a fancy education, because ..." (p. 105)

The male characters tend to view women as domestic workers, think that women's place is in the kitchen. This is also another evidence of gender biased perspectives.

"... Her mother had added some fish balls in the vegetable soup, probably in the hope that this treat would soften her husband's mood." However, this treat does not work as Dawan's father responds in anger, "What is all this talk of Dawan going away to study?" he snapped. "It's too early even to consider it. Let it wait for a few days." (p. 53).

Still, these events show that women's place is in the kitchen and other domestic works, as shown in page 53, “... Dawan rose to collect the dirty dishes ..." In addition, the other female character, Vichai's sister, Bao, also shows the evidence indicating that women are in the domestic area. "... to spend all my time around the baby and the cooking and the washing ..." (p. 60). The evidences are again underlined when Kwai said, "Why go and study more when all you're going to end up doing sooner or later is cook and raise babies anyway, like Mama?" (p. 111).

Women's place is in not in public. Even Dawan herself was influenced by this general assumption of her society. She thinks that her father was right to give bigger opportunity to her brother. She thought,

"And Dawan herself? What could she do? She was just a girl. Wouldn't she grow up just to be a wife and a mother? What could she do with more learning? (p.56)

In the rural society as depicted in the novel, Buddhist monks usually get precious privilege and are highly respected by people. People listen to their advice. "He'll listen to what you say, Sir." (p. 71). Dawan thought that the head Monk would be on her side to solve the problem she faces. "He is a kind old man," Dawan thought, "and if I explain my difficulty perhaps he will help me." (p. 56). Dawan's new found-friend, Bao, also shares Dawan's opinion, "It must be pretty important if you want to see the head monk!" (p. 61). "That old monk is a kind and harmless fellow." (p. 63).

Religious misinterpretation happens when the head monk said, "But you're a girl." (p. 71) and "What can a mere schoolgirl hope to achieve anyway? Be satisfied with what ..." (p. 75).According to Paul in Hoare (2004), the traditional view of women in early Buddhism is that they are inferior. Every nun must bow to every monk.

\section{Mental Violence}

Mental violence and violent intention are among other forms of gender-biased behaviour and actions. Mental violence is described in Dawan's feeling of great fear to the father, as the representative of powerful men, when her father shouts loudly, "Speak? I'll do more than speak to them!" (p. 102). "Damn it, I'll tell you why not!" (p. 105). This sudden and harsh manner of her father makes Dawan feel scared. "I'm scared," she whispered urgently, "I'm real scared inside" (p. 105). 


\section{Violent Intention}

Violent intention as one of the genderbiasedbehaviour and actions could be found in the moment when Dawan's brother, Kwai, argues fiercely towards his sister.

"It's fine for you to spout off ideals like that," her brother interrupted rudely, his voice growing louder and sharper at every sentence. "But what can you do to bring them about? You're only a girl. You won't be able to fight, or to argue loudly, or to lead people in times of crisis. All you're good at is studying -that's how you got the scholarship in the first place." (p. 51)

In another occasion, one of Dawan's classmates, Vichai, violently bullies and tries to make fun of Dawan at classroom.

"Me?" Dawan asked faintly. Behind her Vichai snickered loudly, amidst a general round of giggling in the small classroom. Dawan looked at him in confusion. Why was he deliberately picking on her like this? She glanced around her quickly, and felt as if she was swimming in a sea of wide, taunting eyes. (p. 24)

\section{Physical Violence}

The female characters experience physical violence as shown on page 63 , when Dawan's new-found friend, Bao, shares her experience of being beaten by her brother, Vichai, " ... and most of the time he'll end up fighting me too just to get what he wants."

"That's what you always say, you brat ... He had delivered a stinging slap across Bao's cheek. ... Then he brought his fist down again, hitting Bao sharply on the shoulder." (p. 81)

This male character still continues his violent action, "The anger that smouldered in Vichai's eyes seemed for an instant to catch fire again as he swung out to slap his sister" (p. 83). Kwai, Dawan's brother is also about to hit Bao, "You little busy-body!" He then raised his fist and, like Vichai before him, seem about to strike her.

\section{Marginalization of Women's Role in Society}

Girls in the rural community as depicted in the novel are also marginalized. Girls' place is at home. Conversations about education between Dawan and Kwai show this. "Perhaps girls were not allowed to go after all? Perhaps ..." (p. 49). In the next page, Dawan feels that she is influenced by the received opinion in that community and underlines that boys are in the top priority. Dawan thinks that she is marginalized and has no power to fight against it.

"You know Father has already said that this will be the last year he will pay for my school-fee. ... But you'll have many more chances yet. He said he'll send you to school as long as you want to on studying. (p. 50)

\section{B. The Possible Reasons of Gender- biased Behaviour and Actions in Rural Communities as Depicted in the Novel} Theoretically, society forms communities and these communities can be differentiated by two categories, they are rural and urban, representing both the geographical concept and social matters. Geographically, rural community is characterized by its population density, population size, and distance from urban areas, and distance to other essential services. The place stated in the novel is a rural area of Thailand. The author does not state clearly the exact region as portrayed in the novel. Children who live in rural Thailand are dreaming of better life condition. They see that the lives in the city is much better and promises more wealth than the lives in the villages do. 
Sukanto (1982) highlights the characteristics of a society in rural communities. Rural community is usually identified by its low population density. In the novel, the author describes the environment of the villages. The people can easily find larger spaces to share everything, such as family matters and problems of life, with their neighbours. The availability of public spaces enables the people to strengthen their community bound.

The other characteristics of rural community is the people areinhabiting rural areas and most of their activities are devoted to agriculture, mainly for subsistence farming. "... back bent, planting rice seedlings all day, or watched him knee-deep in mud, plowing furrow after furrow in the wide fields?" (p.18). Families are cultivating rice as the main commodity to earn living or even only to survive.

The people are very earth-bound and conservative, maintaining certain habits and behaviour and other social values for generations such as the interdependence among one another, solidarity, consideration of roles between men and women, et cetera. In addition, the land for farming is considered as a priceless property. The community has paternalistic community system where the main actor in leading and in making decision is male. Women's roles in rural traditional community are considered lower than men's.

The interdependence among the individuals in that community is demonstrated on the event when Dawan and her mother went to Noi's house. They came to see Noi and her husband to ask for a second opinion about Dawan's going to the city (p. 34). The familial bound in that society is well maintained.In the stratified community, abbots and monks often get distinct prestige within communities as it is shown when Dawan and other people come to the head Monk to ask for some pieces of advice. "It must be pretty important if you want to see the head monk." (p. 61)

Yamklinfung (1987) quoted the data presented by Krirkkiat (1985) which showed that in the year of 1975 - 1976 the population below poverty line living in rural areas was $90 \%$ and the percentage of the poor in rural population was $21 \%$ higher compared to those in urban population. It means that most of the poor were living in the rural areas. "The disparities derive from Bangkok's political and cultural dominance over the rest of the country in the tradition of a patrimonial state," (Yamklinfung, 1987: 48). The poverty found in rural populations is worsened by the authority of the rich, here in the novel is represented by the landlords, which draw extra taxes to the peasants.

Gender bias is a social and cultural construction formed during the interaction among the individuals. The culture will interact with biological factors and this later becomes institutionalized. This institution will be a home of socialization where habits and norms are generated to the next generations.

Regarding the discussion in this paper where the main source is the novel, the writer identifies some possible reasons why the male characters commit gender-biased behaviour and actions towards the major female characters. Those possible reasons are among other things cultural construction on women subordination, cultural construction on sex roles stereotyping as the result of patriarchal system, religious misinterpretation, and poverty.

\section{Cultural Construction on Women Subordination}

The first possible reason for the male characters tocommit gender-biased behaviour and actions in the community as described in the novel is the cultural construction which puts women as 
subordinate to men. Such gender biased behaviour derives and roots from early childhood acculturation in the family where girls and boys are introduced differently both in subtle and overt manners. Although parents love their daughters and sons equally, girls are expected to handle larger portions of work responsibilities but granted with fewer advantages than boys do.

In the novel, it is shown that the male characters often consider the female characters as second class, proved by some events occured for instance by assuming that women are best suited to domestic jobs rather than public. "What could she do? She was just a girl." (p. 56) On the other page, “... to spend my time around the baby and the cooking and the washing ..."(p.60) On p. 111 it can also be found the evidence of placing the female characters into the second class, "Why go and study more when all you're going to end up doing sooner or later is cook and raise babies, anyway."

Subordination of women happens in the assumption that higher education is not for girls and that girls are less encouraged than boys in pursuing higher studies. "Their parents had considered it foolish and wasteful to send girls to school." (p. 14). Simone de Beauvoir, as cited by Eisenstein (1983) stated that subordination was generated from the assumption that men tended to view women as extremely different from themselves.

\section{Cultural Construction on Sex Roles Stereotyping as the Result of Patriarchal System}

The second reason is sex roles stereotyping as the product of patriarchal system. Stereotyping of women is taking women only into the domestic job and to serve men or husband and to take care of the children. "What could she do? She was just a girl. Wouldn't she grow up just to be a wife and a mother? What could she do with more learning?" (p.56).
Patriarchal system and religious interpretation are interrelated. Buddhism, for instance, never teaches its followers to view women as less important than men. Hoare (2004) states that although mothers, daughters, and sisters might be deeply loved and honored, a greater respect towards males is obvious in families and monasteries where traditional values are most carefully preserved. Nevertheless, the traditional society system hinders the practices of balanced view towards the roles of men and women.

Sex role is "a role assigned to the actor because of the gender-associated behaviour linked by society with that biological sex."Haralambos (1996) and Jeneway and Millet in Eisenstein (1983: 11). Eisenstein (1983) also finds that the ideology of sex-roles becomes the major cause of this continuous subordination of woman. Jeneway and Millet as quoted by Eisentein (1983) conclude that sex-role is a form of oppression to keep women restricted and limited in their scope.

Women are associated with lower order of social or cultural organization, domestic and private sphere, as seen in the novel when Kwai argued his sister, Dawan.

"Why go and study more when all you're going to end up doing sooner or later is cook and raise babies anyway, like Mama?" (p. 111)

Another event shows how girls in that community are perceived as the second sex. It can be inferred from Dawan's thought below:

"And Dawan herself? What could she do? She was just a girl. Wouldn't she grow up just to be a wife and a mother? What could she do with more learning? (p.56)

Men, on the other hand, tend to be associated with public sphere, higher order, and they should be looking for family 
subsistence, chief of the family, decision maker, and so on. These kinds of sex-role stereotyping become the means by which the entire society keeps women as subject to the rules of the patriarchy (Eisenstein, 1983: 6), as seen when Dawan's father says, "But I certainly have the power to do so." (p. 104). The men are the decision maker and women are not used to making decision, as represented by Dawan's mother. "It's not my place to say anything." (p. 32)

It is the social mythology or a set of beliefs about roles telling that women belong to the domestic areas as the major duty. This is enough to induce the assumption that women are subordinated to the realms of other kinds of power available in public sphere such as intellectual, economic, and political.

\section{Religious Misinterpretation}

The third reasonis religious misinterpretation. The early Buddhism texts also state that every nun must bow to every monk. In the novel, it is found that the head Monk as the representation of Buddhist clergymen, said, "But you're a girl." (p. 71) and "What can a mere schoolgirl hope to achieve anyway? Be satisfied with what ..." (p. 75). The head Monk fails to free himself from the received public opinion about the position of women in the society by reacting such way to argue Dawan's will to go studying at the City school.

Simone de Beauvoir (1972) criticizes that religion is a deceptive instrument as it encourages women to accept their secondary status on earth and promising equality in heaven, including in Asian Buddhist communities (Hoare, 2004). Like gender which causes conflicts and discrimination among the social groups, religious beliefs which are found in all societies, are also one of the most enduring reasons of conflict and inequalities (Haralambos, 1996). Religious symbolism has damaging effects on women as most of religious symbolisms are malecentred. This condition impacts on women's psychology, making them accept dependence and inferiority as normal and it pervades into the social structure, legitimates the domination of male in the home and the society as a whole (Haralambos, 1996).

\section{Poverty}

The fourth reason is poverty. Women tend to be put in the second priority if the family where the women live is living in abject poverty, as seen in this illustration.

Noi blurted out, "Do you know what children from poor families usually do after school to feed themselves?" Her voice was low and sullen. "The younger ones carry little boxes cigarettes and foreign candies around their necks, trying to sell some to people on the steps of movie theatres at night, people who either ignore them or swat at them as if the children were a pack of flies." (p.40)

Living in such a condition, the resource of the family will be projected to the most profitable sector. Sons will have the priority in getting education. Dawan's father refuses to discuss the scholarship won by his daughter. He considers that it must be better if his son wins the scholarship. "What is all this talk of Dawan going away to study?" he snapped. "It's too early even to consider it. Let it wait for a few days" (p. 53).

The household resource allocation theory shows that poverty will dismiss daughters' opportunity to attend school. The decision maker of the house, a father, tends to think twice to spend extra money for the daughter's education. Girls will leave home to live with their husbands. "And Dawan herself? What could she do? She was just a girl. Wouldn't she grow up just to be a wife and a mother? What could she do with more learning?" (p.56). 
Sons or boys, conversely, do not leave the nucleus family and it is beneficial to the family because later these boys can help the family to earn better living. "You're a boy, and more schooling would have been useful for you. ... with more schooling, you could find good jobs, and earn some money to help the family" (p. 55).

\section{CONCLUSIONS}

The female characters playing important parts in this novel are Dawan, as the main character, Dawan's mother, Dawan's cousin Noi, and Dawan's friend Bao. These female characters are experiencing gender biased treatment such as subordination of women, mental violence, violent intention, physical violence, sex role stereotyping, and marginalization. The subordination of women manifests in the behaviour and actions like assuming that it is useless to send girls to school and seeing women as weak and powerless. The mental violence is demonstrated in the behaviour and actions like scolding, shouting, and threatening the female characters shown by the male characters. The violent intention, on the other hand, is shown in the action of making fun one of the female characters before the public and fierce argumentation to weaken the female main character in pursuing and defending her ideals.

The physical violence manifests in the actions like slapping, beating, fighting, and squinting savagely the rice the male character shoved at the female main character's face. The facts found in the novel that most of the female characters are thought to do domestic job and to be placed at the domestic spheres are showing the manifestation of sex role stereotyping. The marginalization of women in that novel happens in the behaviour and actions like taking for granted the general assumption that girls are better to stay at home rather than putting themselves in high position or rank in the society structure.
These gender-biased treatments in the novel are caused by four possible factors, namely cultural construction on women subordination, cultural construction on sex roles stereotyping as the result of patriarchal system, religious misinterpretation, and poverty. This rural community as depicted in the novel is the product of rural society. The society forms certain values which are then maintained by the local community as shown in the novel.

\section{REFERENCES}

Abcarin, R., Marvin K., \& Peter R. (1988). Literature: Reading and writing the human experience. New York: St. Martin's Press

Abrams, M.H. (1981). A glossary of literary terms. (3rd Ed.). New York: Holt, Rinehart and Winston Inc.

Cheal, D. (2002). Sociology of family life. New York: Palgrave.

Das, B. K. (2002). The twentieth century literature criticism. New Delhi: Mehra Offset Press

Edgar, A. \& Sedgwick, P. (2002). Cultural theory: The key concepts. London: Routledge.

Eisenstein, H. (1983). Contemporary feminist thoughts. Massachusettes: G.K. Hall \& Co.

Fakih, M. (2010). Analisis gender dan transformasi sosial. Yogyakarta: Pustaka Pelajar.

Glover, D. \& Cora K. (2005). Genders. Oxford: Routledge.

Haralambos, M., et al. (1996). Sociology: themes and perspectives. South Melbourne: Addison Wesley Longman Australia Pty. Limited.

Ho, M. (2006). Sing to the dawn. Singapore: Marshall Cavendish International (Asia) Private Limited. 
Hoare, D. T. (2004). Thailand: A global studies handbook. California: ABC Clio.

Langland, E. (1984). Society in the novel. North Carolina: The University of North Carolina Press.

Madden, D. (2009). Novel and society. Microsoft $\AA$ Encarta $\AA$ 2009. (C 19932008 Microsoft Corporation

Megawangi, R. (1999). Membiarkanberbeda: Sudutpandangbarutentangrelasi gender. Bandung: Mizan.

Soekanto, S. (1995). Sosiologi: Suatu pengantar. Jakarta: PT. RajaGrafindo Persada.

Tharp, R. G., \&Gallimore, R. (1988). Rousing minds to life: Teaching, learning, and schooling in social context. Cambridge, England: Cambridge University Press.

Wellek, R. \& Maitland, D. (1971). Theory of literature. (3rd Ed). New York: A Harvest Book Harcout, Brace, and World, Inc.

Yamklinfung, P. (1987). Economic development and rural-urban disparities in thailand. Southeast asian studies. Vol. 25, No.3, December 1987.

\section{Sources from the Internet}

Lantolf, J. P. (n.d.). Introducing socioculturaltheory. Retrieved September 14, 2011, from http:// fds.oup.com/www.oup.com/pdf/elt/ catalogue/0-9-442160-0-a.pdf

Rural Society. http://www.britannica.com/ EBchecked/topic/512976/ruralsociety.

Thailand: Rural social patterns. The library of congress country studies, Retrieved April 15, 2012, from

http://www.photius.com / countries / thailand/society/thailand_society_ rural_social_pattern-2357.html.

Thailand: The social system. The library of congress country studies, Retrieved April 15, 2012, from

http://www.photius.com/countries / thailand/society/thailand_the_ social_system.html. 